\title{
ВЛИЯНИЕ ГЛОБУЛЯРНЫХ БЕЛКОВ НА ИНТЕНСИВНОСТЬ ЭКСТРАГИРОВАНИЯ АНТОЦИАНОВОГО ПИГМЕНТА ИЗ ЯГОДНОГО СЫРЬЯ
}

N.Yu. Chesnokova, L.V. Levochkina, A.A. Kuznetsova, L.V. Kushnarenko

\section{THE INFLUENCE OF GLOBULAR PROTEINS ON THE DEGREE OF SEPARATION OF ANETOCYANIN PIGMENT FROM BERRY RAW MATERIALS}

\author{
Чеснокова Наталья Юрьевна - канд. биол. \\ наук, доц. Департамента пищевых наук и техно- \\ логий Школы биомедицины Дальневосточного \\ федерального университета, г. Владивосток. \\ E-mail: chesn_natali@mail.ru
}

Левочкина Людмила Владимировна - канд. техн. наук, проф. Департамента пищевых наук и технологий Школы биомедицины Дальневосточного федерального университета, г. Владивосток. E-mail: vovslev@yandex.ru

Кузнецова Алла Алексеевна - канд. техн. наук, доц. Департамента пищевых наук и технологий Школы биомедицины Дальневосточного федерального университета, г. Владивосток.

E-mail: alku1965@mail.ru

Кушнаренко Людмила Владимировна - канд. техн. наук, доц. Департамента пищевых наук и технологий Школы биомедицины Дальневосточного федерального университета, г. Владивосток. E-mail: karavai831@mail.ru

Изучено влияние полимеров белковой природы - яичного альбумина и БСА (бычьего сывороточного альбумина) на интенсивность извлечения антоцианового пигмента жимолости и черной смородины. Установлено, что введение в систему яичного альбумина и БСА влияет на интенсивность извлечения антоцианового пигмента. Введение в раствор 0,1 \% яичного альбумина или БСА позволяет наиболее интенсивно выделять антоциановый пигмент из ягодного сырья. Степень извлечения антоцианового пигмента из ягод жимолости и черной смородины в присутствии 0,1 \% яичного альбумина увеличивается в 1,5 и 0,8 раза, в присутствии 0,1 \% БСА повышается в 1,2 и 1,6 раза соответственно. Увеличение содержания белков в системе приводит к снижению интенсивности извлече-
Chesnokova Natalya Yuryevna - Cand. Biol. Sci., Assoc. Prof., Department of Food Sciences and Technologies, School of Biomedicine, Far Eastern Federal University, Vladivostok.

E-mail: chesn_natali@mail.ru

Levochkina Lyudmila Vladimirovna - Cand. Techn. Sci., Prof., Department of Food Sciences and Technologies, School of Biomedicine, Far Eastern Federal University, Vladivostok.

E-mail: vovslev@yandex.ru

Kuznetsova Alla Alexeyevna - Cand. Techn. Sci., Assoc. Prof., Department of Food Sciences and Technologies, School of Biomedicine, Far Eastern Federal University, Vladivostok.

E-mail: alku1965@mail.ru

Kushnarenko Lyudmila Vladimirovna - Cand. Techn. Sci., Assoc. Prof., Department of Food Sciences and Technologies, School of Biomedicine, Far Eastern Federal University, Vladivostok.

E-mail: karavai831@mail.ru

ния антоцианового пигмента. Степень извлечения антоцианового пигмента из ягод жимолости и черной смородины при содержании в растворе $4 \%$ БСА уменьшается в 1,8 и 5 раз соответственно. Повышение количества яичного альбумина до 4 \% приводит к помутнению раствора антоцианового пигмента. Установлена зависимость степени извлечения антоцианового пигмента от рH раствора, содержащего пигмент и белок. Показано, что максимальной степени извлечения соответствует наименьшее значение $\mathrm{pH}$ раствора. Значения $\mathrm{pH}$ раствора антоцианового пигмента жимолости и черной смородины в присутствии $1 \%$ яичного альбумина составляет 3,66 и 3,46, в присутствии $1 \%$ БСА - 3,90 и 3,46 соответственно. Увеличение содержания в растворе белка приводит 
$к$ повышению его рН. Разработана технология приготовления зефира с добавлением комплекса «антоциановый пигмент - яичный альбумин». Наилучшими органолептическими показателями обладал зефир с добавлением комплекса, содержащего $6 \%$ антоцианового пигмента и 2 \% яичного альбумина. Кроме того, зефрир с добавлением комплекса, содержащего $6 \%$ антоцианового пигмента и 2 \% яичного альбумина, имел пьшную однородную консистенцию и хорошую формоустойчивость.

Ключевые слова: черная смородина, жимолость, антоциановый пигмент, яичный альбумин, бычий сьвороточный альбумин, комплекс «антоциановый пигмент - яичный альбумин», зесрир.

The influence of polymers of protein nature - egg albumin and bovine serum albumin, on the extraction rate of anthocyanin pigment honeysuckle and black currant was studied. It was found that the introduction of egg albumin and bovine serum albumin into the system affected the intensity of extraction of anthocyanin pigment. The introduction of $0.1 \%$ egg albumin and bovine serum albumin into the solution allowed the most intensive isolation of anthocyanin pigment from the honeysuckle and black currant. The degree of extraction of anthocyanin pigment from honeysuckle and black currant at $0.1 \%$ egg albumin increased by 1.5 and 0.8 times, in presence of $0.1 \%$ bovine serum albumin increased by 1.2 and 1.6 times, respectively. An increase in protein content in the system led to the decrease in the intensity of anthocyanin pigment extraction. The degree of extraction of anthocyanin pigment from honeysuckle and black currant with the content of $4 \%$ bovine serum albumin in the solution decreased by 1.8 and 5 times, respectively. Increasing the amount of egg albumin to $4 \%$ led to clouding of anthocyanin pigment solution. The dependence of the degree of extraction of anthocyanin pigment on $\mathrm{pH}$ of pigment and protein solution was established. It was shown that the lowest $\mathrm{pH}$ of the system corresponded to the maximum degree of extraction. The values of $\mathrm{pH}$ of anthocyanin pigment of honeysuckle and blackcurrant in the presence of $1 \%$ egg albumin were 3.66 and 3.46; in the presence of $1 \%$ bovine serum albumin they were 3.9 and 3.46 , respectively. An increase in protein content in the system led to the increase in $\mathrm{pH}$ of the system. The technology was developed for the preparation of marshmallows with the addition of anthocyanin pigment-egg albumin complex. Marshmallows with the addition of the complex containing $6 \%$ anthocyanin pigment and
$2 \%$ egg albumin possessed the best organoleptic characteristics. In addition, the marshmallows with the addition of the complex containing $6 \%$ anthocyanin pigment and $2 \%$ egg albumin had f luffy uniform consistency and good shape stability.

Keywords: black currant, honeysuckle, anthocyanin pigment, egg albumin, bovine serum albumin, anthocyanin pigment-egg albumin complex, marshmallows.

Введение. В настоящее время уделяется большое внимание здоровому питанию, и у потребителей популярными становятся безопасные продукты высокого качества, содержащие биологически активные вещества и обладающие выраженными фрармакологическими и антирадикальными свойствами. Здоровая пища должна оказывать на организм человека лечебное действие, помогать бороться со стрессами и неблагоприятным воздействием окружающей среды. В этой связи возрастает интерес к натуральным ингредиентам, содержащим биологически активные и вкусо-ароматические вещества, которые придают готовым продуктам не только привлекательный вид, но и естественный аромат, вкус и повышают пищевую ценность.

Среди натуральных растительных ингредиентов, способных придавать продуктам широкие спектры цветовых оттенков, а также обеспечивать их вкусовые характеристики, важное место занимают антоциановые пигменты. По своей структуре антоцианы представляют собой фенольные соединения, являющиеся моно- и дигликозидами, содержащими в качестве агликона антоцианидинагидрокси- и метоксизамещенные соли фрлавилия (2-фенилхроменилия) [1].

Экстракты антоциановых пигментов, кроме красящих компонентов, содержат в своем составе полезные биологически активные вещества: витамины, гликозиды, органические кислоты, микроэлементы. Данные соединения обладают множеством полезных фрармакологических свойств: снижают уровень вредного холестерина, препятствуют образованию тромбов, повышают эластичность сосудов, ускоряют заживление ран, благоприятно влияют на зрение, способствуют профилактике онкологических заболевании [2-4]. Кроме того, антоциановые пигменты обладают выраженной антирадикальной активностью $[5,6]$.

Существует множество способов интенсификации экстрагирования антоциановых пигментов [7-9] из растительного сырья, однако вопрос использования новых технологий для более полного 
извлечения пигментов остается актуальным. Кроме того, многие соединения, используемые для выделения антоциановых пигментов, способны образовывать с ними стойкие комплексы [10], что может оказывать существенное влияние на их свойства и, в конечном счете, на качество готовых изделий, изменяя их характеристики.

Цель работы. Исследование влияния полимеров белковой природы на интенсивность экстрагирования антоцианового пигмента, выделенного из жимолости и черной смородины, и использования комплекса антоциановый пигмент - яичный альбумин для производства зефира.

Задачи исследования: установление влияния яичного и бычьего сывороточного альбуминов на интенсивность экстрагирования антоцианового пигмента, выделенного из жимолости и черной смородины, а также исследование возможности использования комплекса пигмент - белок в производстве зефира.

Объекты и методы исследования. В качестве объектов для выделения антоцианового пигмента использовали ягоды жимолости (Lonicera tatarica L.) и черной смородины (Ríbes nígrum). Экстракцию проводили водными $(0,1$; 0,5; 2 и 4 \%) растворами яичного альбумина и БСА (бычьего сывороточного альбумина).

Грубоизмельченное размороженное ягодное сырье обрабатывали водными растворами яич- ного альбумина и БСА в соотношении 6:100 при $70{ }^{\circ} \mathrm{C}$ в течение 1 ч, затем отфильтровывали. Интенсивность окраски растворов определяли по величине оптической плотности на спектрофотометре «SHIMADZUUV-1800» (Япония) в интервале длин волн 400-800 нм.

Измерение влаги полученных изделий проводили в соответствии с требованиями ГОСТ 5900-2014. Определение массовой доли золы, нерастворимой в растворе соляной кислоты с массовой долей $10 \%$ в зефире, проводили в соответствии с ГОСТ 5901-2014. Определение массовой доли сернистой кислоты в зефире - в соответствии с ГОСТ 26811-14.

Результаты исследования и их обсуждение. Поскольку производство продуктов питания это сложный процесс, сопровождающийся физико-химическими взаимодействиями между компонентами дисперсной системы, оказывающими существенное влияние на качество готовых изделий, было целесообразно изучить влияние некоторых компонентов, в частности студнеобразователей белковой природы - яичного альбумина и БСА, на интенсивность извлечения антоцианового пигмента жимолости и черной смородины. Зависимость интенсивности извлечения антоцианового пигмента жимолости и черной смородины от содержания в реакционной среде яичного альбумина и БСА представлена на рисунках1 и 2.
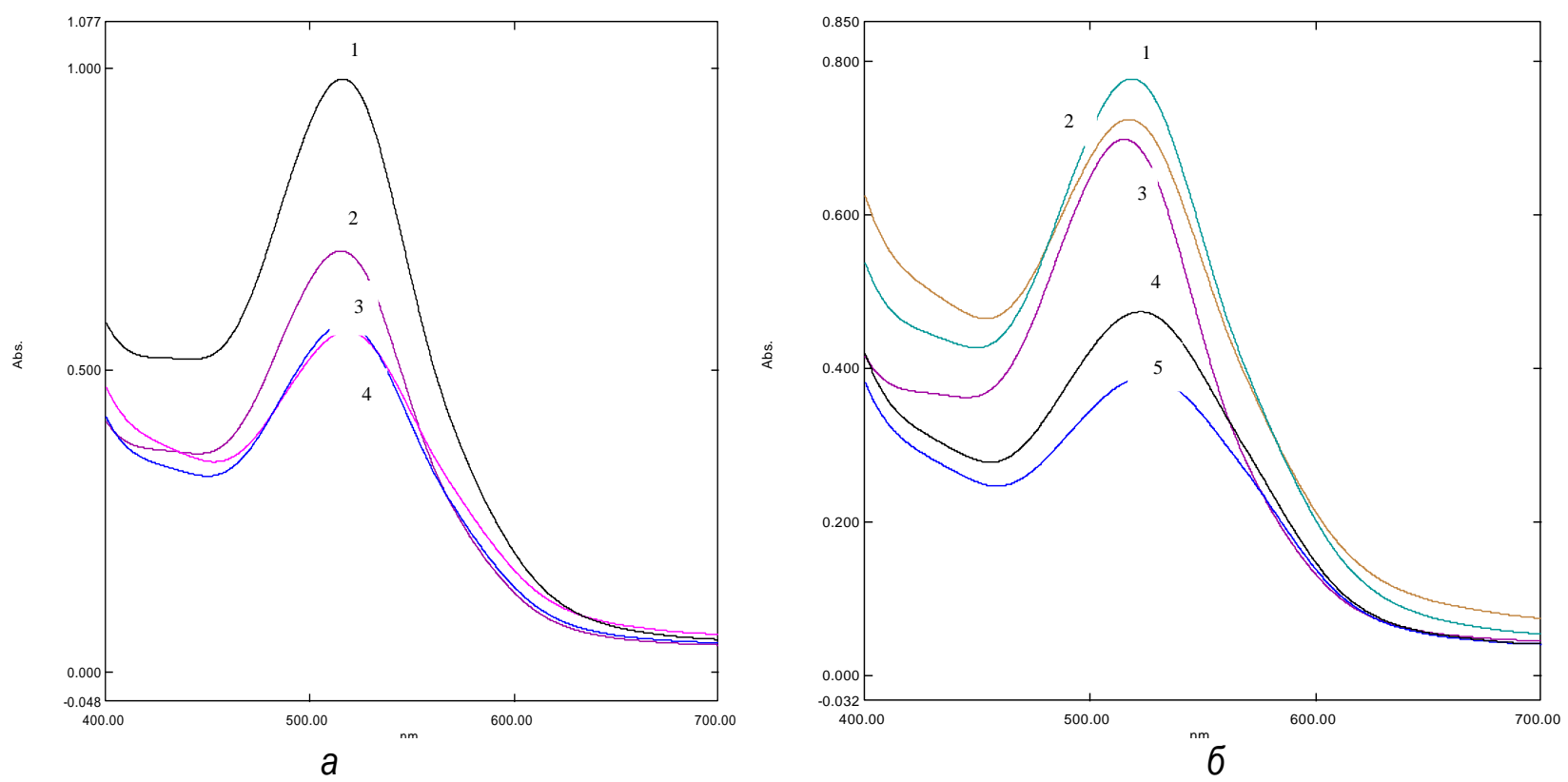

Puc. 1. Зависимость интенсивности извлечения антоцианового пигмента жимолости от присутствия в реакционной среде: а - яичного альбумина: 1 - 0,1\%; 2 - антоциановый пигмент без добавления белка; 3- 0,5 \%; 4 - $2 \%$;

б - БСА: 1 - 0,1 \%; 2 - 0,5 \%; 3 - антоциановый пигмент без добавления белка; 4 - 2 \%; 5 - 4\% 

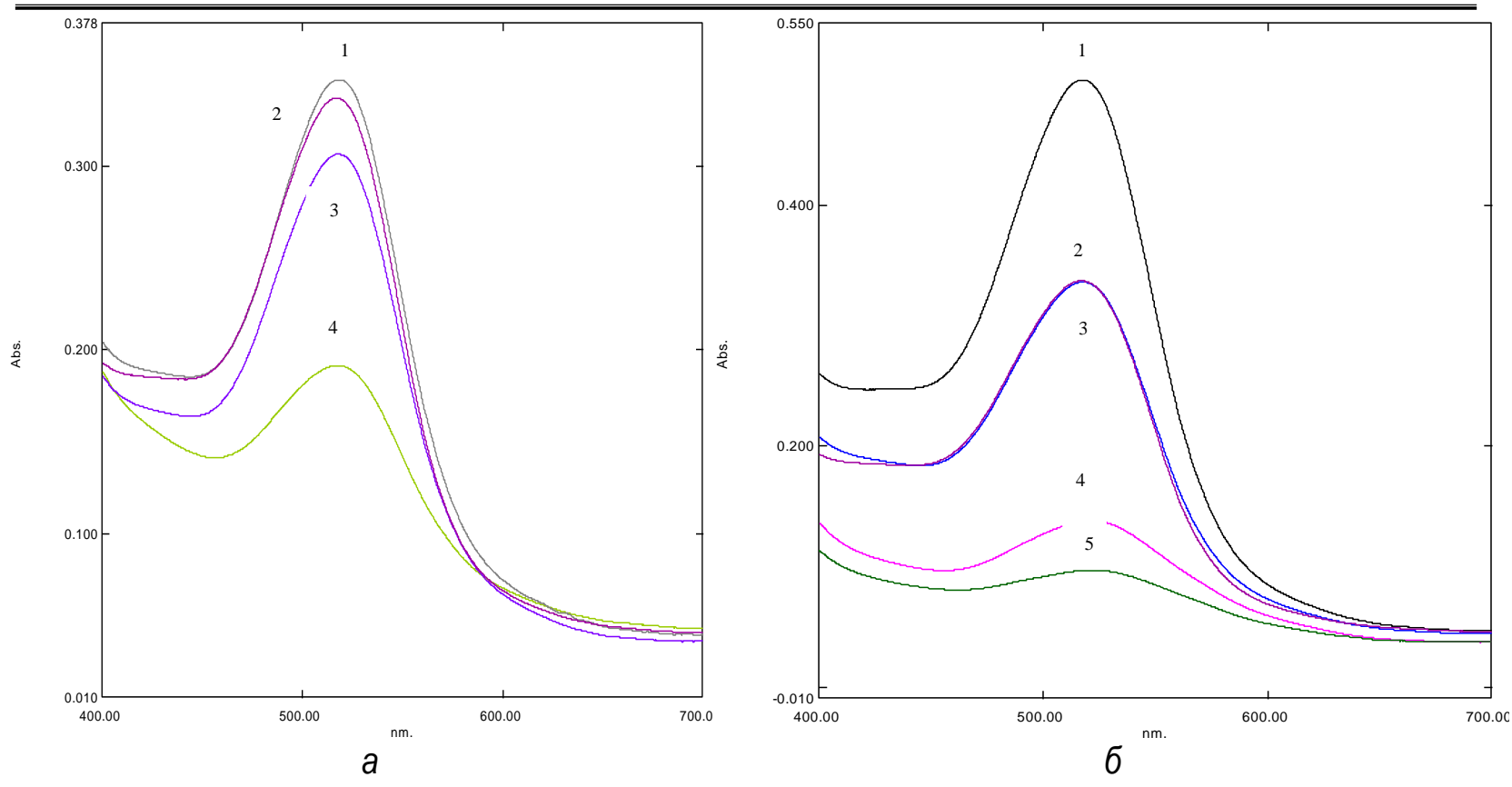

Puс. 2. Зависимость интенсивности извлечения антоцианового пигмента черной смородины от присутствия в реакционной среде: а - яичного альбумина: 1 - 0,1\%; 2 - антоциановый пигмент без добавления белка; 3 - 0,5 \%; 4 - $2 \%$; б - БСА: 1 - 0,1\%; 2 - 0,5\%; 3 - антоциановый пигмент без добавления белка; 4 - $2 \% ; 5$ - 4 \%

Из представленных результатов видно, что интенсивность извлечения антоцианового пигмента зависит от присутствия в реакционной среде исследуемых полимеров белковой природы - яичного альбумина и БСА. Максимальное извлечение антоцианового пигмента жимолости и черной смородины наблюдается при введении в испытуемый раствор 0,1 \% яичного альбумина. Степень извлечения пигмента увеличивается в 1,5 и 0,8 раза соответственно. Установлено, что повышение содержания яичного альбумина в растворе приводит к снижению интенсивности извлечения антоцианового пигмента. Введение в систему $2 \%$ яичного альбумина снижает степень извлечения антоцианового пигмента жимолости и черной смородины в 1,2 и 1,6 раза соответственно. Повышение количества яичного альбумина до 4 \% приводит к помутнению раствора антоцианового пигмента, что говорит о коагуляционных изменениях в молекуле белка.

Максимум извлечения антоцианового пигмента жимолости и черной смородины в присутствии БСА (рис. 2) также наблюдается при 0,1 \% содержании белка в растворе. Степень извлечения антоцианового пигмента в присутствии 0,1\% БСА увеличивается в 1,2 и 1,6 раза соответственно. При дальнейшем добавлении БСА наблюдается, как и в присутствии яичного альбумина, снижение интенсивности извлечения антоцианового пигмента. Степень извлечения антоцианового пигмента при содержании в растворе 4 \% БСА уменьшается в 1,8 и 5 раз соответственно.

Как было отмечено раннее [11], разное влияние белков на степень извлечения антоцианового пигмента зависит от $\mathrm{pH}$ системы. Значения $\mathrm{pH}$ растворов антоцианового пигмента жимолости и черной смородины в присутствии яичного альбумина и БСА представлены на рисунках 3 и 4.

Анализ зависимости интенсивности окраски системы пигмент - белок (см. рис. 1 и 2) от величины $\mathrm{pH}$ растворов антоцианового пигмента жимолости и черной смородины в присутствии яичного альбумина и БСА показывает, что максимальной степени извлечения соответствует наиболее кислая среда. Значения $\mathrm{pH}$ системы антоцианового пигмента жимолости и черной смородины в присутствии $1 \%$ яичного альбумина составляет 3,66 и 3,46 соответственно. Значения $\mathrm{pH}$ системы антоцианового пигмента жимолости и черной смородины в присутствии $1 \%$ БСА составляет 3,90 и 3,46 соответственно. Увеличение содержания в системе белка приводит к повышению рН системы, в данном случае независимо от вида исследуемого белка. Так, при введении в раствор антоцианового пигмента жимолости и черной смородины $2 \%$ 
яичного альбумина значения $\mathrm{pH}$ системы увеличиваются и достигают 4,10 и 3,74 соответственно. Аналогичное повышение $\mathrm{pH}$ раствора наблюдается при использовании для выделе- ния антоцианового пигмента 0,5 \%, 2 и 4 \% БСА. Значения рН антоцианового пигмента жимолости и черной смородины в присутствии $4 \%$ БСА составляют 4,55 и 4,30 соответственно.

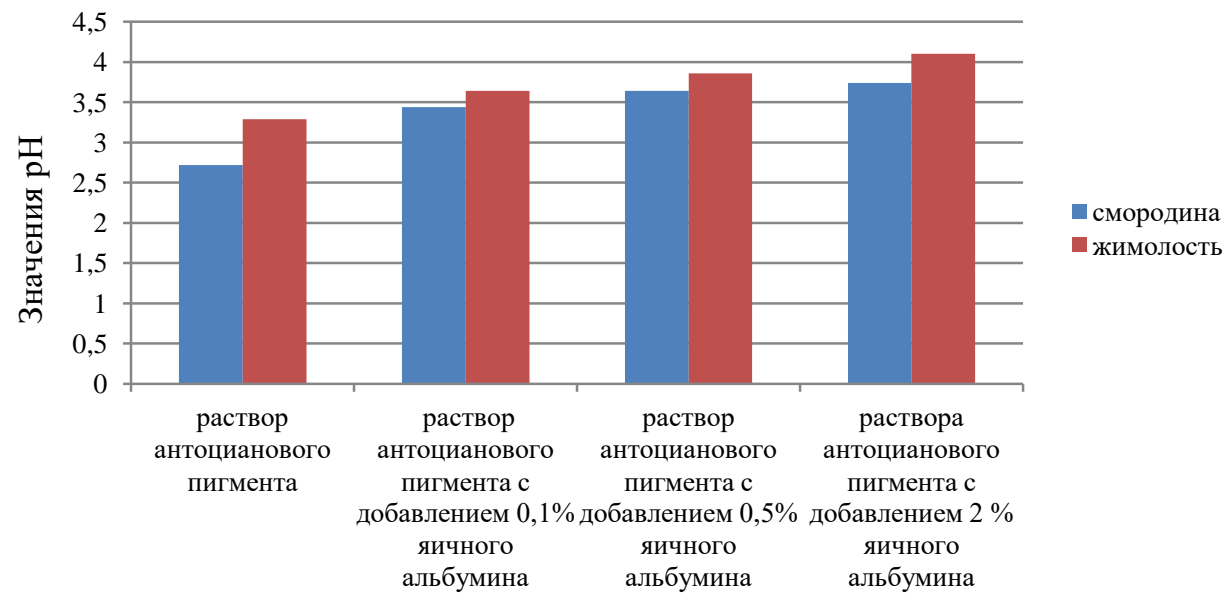

Puс. 3. pH растворов антоцианового пигмента с добавлением яичного альбумина

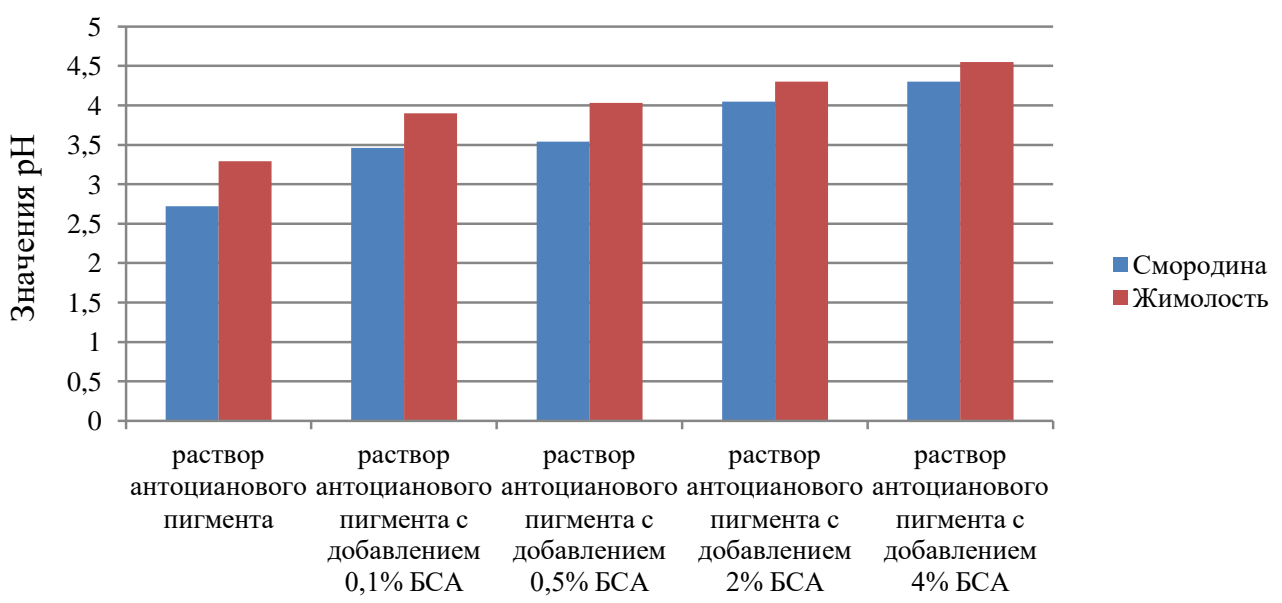

Pис. 4. pH раствора антоцианового пигмента с добавлением БСА

В кислой среде, по-видимому, наблюдается более полное связывание положительно заряженных аминогрупп молекулы белка с $\mathrm{OH}$ группами антоцианов. Увеличение содержания белков в системе антоцианового пигмента увеличивает значения рН системы и приближает ее к значениям ИЭТ белков (ИЭТ альбумина - 4,8, БСА - 4,9), где наблюдается наименьшее взаимодействие яичного альбумина и БСА с молекулами антоцианов за счет снижения степени ионизации белков.
Таким образом, введение в раствор антоцианового пигмента белков влияет на интенсивность извлечения антоцианового пигмента. Наиболее интенсивно антоциановый пигмент выделяется в присутствии 0,1 \% яичного альбумина и БСА. Увеличение белков в системе приводит к падению интенсивности извлечения антоцианового пигмента.

Применение антоцианового пигмента весьма перспективно для окраски желированных десертов в розовые и красные цвета. В качестве объ- 
екта окрашивания был выбран зесрир. Зесир готовили по унифицированной рецептуре в соответствии с классической технологией [12], заменяя воду на раствор антоцианового пигмента. В антоциановый пигмент жимолости и черной смородины добавляли в виде жидкого комплекса яичный альбумин. Было приготовлено четыре образца зефира с добавлением комплекса, содержащего антоциановый пигмент и 1-4 \% яичного альбумина. Количество пигмента, входящего в изделие, было определено в предыдущих исследованиях [11], где показано, что наилучшими органолептическими показателями обладал зефир, содержащий 6 \% раствор антоцианового пигмента.

Органолептическая оценка образцов зефира с добавлением комплекса антоциановый пигмент - яичный альбумин представлена в таб- лицах 1 и 2. В качестве контроля использовали зефир без добавления комплекса.

Наилучшими органолептическими показателями обладал зефир с добавлением комплекса, содержащего $6 \%$ антоцианового пигмента черной смородины и 2 \% яичного альбумина. При данном содержании антоцианового пигмента и ячного альбумина зесрир приобретал розовофиолетовый либо розовый цвет и насыщенный горько-сладкий вкус жимолости или кислосладкий смородиновый вкус. Кроме того, зефир с добавлением комплекса, содержащего $6 \%$ антоцианового пигмента и 2 \% яичного альбумина, имел пышную однородную консистенцию и хорошую формоустойчивость.

Физико-химические показатели и показатели безопасности зефира с добавлением комплекса антоциановый пигмент - яичный альбумин представлены в таблице 3.

Таблица 1

\section{Органолептическая оценка образцов зефира с добавлением комплекса антоциановый пигмент жимолости - яичный альбумин}

\begin{tabular}{|c|c|c|c|c|c|}
\hline Показатель & Контроль & $\begin{array}{c}\text { Комплекс анто- } \\
\text { циановый пиг- } \\
\text { мент - } 1 \% \text { яич- } \\
\text { ный альбумин }\end{array}$ & $\begin{array}{c}\text { Комплекс ан- } \\
\text { тоциановыцй } \\
\text { пигмент - } 2 \% \\
\text { яичный альбу- } \\
\text { мин } \\
\end{array}$ & $\begin{array}{c}\text { Комплекс анто- } \\
\text { циановый пиг- } \\
\text { мент - } 3 \% \text { яич- } \\
\text { ный альбумин }\end{array}$ & $\begin{array}{c}\text { Комплекс анто- } \\
\text { циановый пиг- } \\
\text { мент - } 4 \text { \% яич- } \\
\text { ный альбумин }\end{array}$ \\
\hline Внешний вид & $\begin{array}{c}\text { Белая воз- } \\
\text { душная масса }\end{array}$ & $\begin{array}{c}\text { Розово- } \\
\text { фиолетовая } \\
\text { воздушная масса }\end{array}$ & $\begin{array}{c}\text { Розово- } \\
\text { фиолетовая } \\
\text { воздушная } \\
\text { масса }\end{array}$ & $\begin{array}{c}\text { Розово- } \\
\text { фиолетовая } \\
\text { воздушная масса }\end{array}$ & $\begin{array}{c}\text { Бледно- } \\
\text { фиолетовая } \\
\text { воздушная масса }\end{array}$ \\
\hline $\begin{array}{l}\text { Формоустой- } \\
\text { чивость }\end{array}$ & $\begin{array}{l}\text { Имеет рав- } \\
\text { номерную } \\
\text { форму, со- } \\
\text { храняет ри- } \\
\text { сунок на по- } \\
\text { верхности }\end{array}$ & $\begin{array}{c}\text { Расплывается, } \\
\text { не имеет четкой } \\
\text { формы, не со- } \\
\text { храняет рисунок } \\
\text { на поверхности }\end{array}$ & $\begin{array}{l}\text { Имеет равно- } \\
\text { мерную форму, } \\
\text { сохраняет ри- } \\
\text { сунок на по- } \\
\text { верхности }\end{array}$ & $\begin{array}{c}\text { Имеет равно- } \\
\text { мерную форму, } \\
\text { сохраняет рису- } \\
\text { нок на поверхно- } \\
\text { сти }\end{array}$ & $\begin{array}{c}\text { Расплывается, не } \\
\text { имеет четкой } \\
\text { формы, не со- } \\
\text { храняет рисунок } \\
\text { на поверхности }\end{array}$ \\
\hline Цвет & Белый & $\begin{array}{l}\text { Выраженный } \\
\text { розово- } \\
\text { фиолетовый }\end{array}$ & $\begin{array}{l}\text { Выраженный } \\
\text { розово- } \\
\text { фиолетовый }\end{array}$ & $\begin{array}{l}\text { Выраженный } \\
\text { розово- } \\
\text { фиолетовый }\end{array}$ & $\begin{array}{c}\text { Бледно- } \\
\text { фиолетовый }\end{array}$ \\
\hline $\begin{array}{l}\text { Консистен- } \\
\text { ция }\end{array}$ & $\begin{array}{l}\text { Воздушная } \\
\text { однородная }\end{array}$ & $\begin{array}{c}\text { Жидкая одно- } \\
\text { родная }\end{array}$ & $\begin{array}{l}\text { Воздушная } \\
\text { однородная }\end{array}$ & $\begin{array}{l}\text { Воздушная } \\
\text { однородная }\end{array}$ & $\begin{array}{l}\text { Жидкая, неодно- } \\
\text { родная, с вклю- } \\
\text { чениями коагули- } \\
\text { рованного белка }\end{array}$ \\
\hline Запах & $\begin{array}{c}\text { Легкий запах } \\
\text { печеных яб- } \\
\text { лок }\end{array}$ & $\begin{array}{c}\text { Выраженный } \\
\text { запах жимолости }\end{array}$ & $\begin{array}{c}\text { Выраженный } \\
\text { запах жимоло- } \\
\text { сти }\end{array}$ & $\begin{array}{c}\text { Выраженный } \\
\text { запах жимолости } \\
\text { и яичного альбу- } \\
\text { мина } \\
\end{array}$ & $\begin{array}{c}\text { Выраженный за- } \\
\text { пах жимолости и } \\
\text { яичного альбуми- } \\
\text { на } \\
\end{array}$ \\
\hline Вкус & Сладкий & $\begin{array}{c}\text { Насыщенный } \\
\text { кисло-сладкий } \\
\text { вкус с характер- } \\
\text { ной горечью }\end{array}$ & $\begin{array}{c}\text { Насыщенный } \\
\text { кисло-сладкий } \\
\text { вкус с харак- } \\
\text { терной горечью }\end{array}$ & $\begin{array}{c}\text { Насыщенный } \\
\text { кисло-сладкий } \\
\text { вкус с характер- } \\
\text { ной горечью }\end{array}$ & $\begin{array}{c}\text { Насыщенный } \\
\text { кисло-сладкий } \\
\text { вкус с характер- } \\
\text { ной горечью }\end{array}$ \\
\hline
\end{tabular}


Органолептическая оценка образцов зефира с добавлением комплекса антоциановый пигмент черной смородины - яичный альбумин

\begin{tabular}{|c|c|c|c|c|c|}
\hline Показатель & Контроль & $\begin{array}{c}\text { Комплекс } \\
\text { антоциановый } \\
\text { пигмент - 1\% } \\
\text { яичный аль- } \\
\text { бумин }\end{array}$ & $\begin{array}{c}\text { Комплекс } \\
\text { антоциановый } \\
\text { пигмент - } 2 \% \\
\text { яичный аль- } \\
\text { бумин }\end{array}$ & $\begin{array}{c}\text { Комплекс } \\
\text { антоциановый } \\
\text { пигмент - 3\% } \\
\text { яичный аль- } \\
\text { бумин }\end{array}$ & $\begin{array}{c}\text { Комплекс } \\
\text { антоциановый } \\
\text { пигмент - 4\% } \\
\text { яичный альбумин }\end{array}$ \\
\hline Внешний вид & $\begin{array}{c}\text { Белая воз- } \\
\text { душная мас- } \\
\text { са }\end{array}$ & $\begin{array}{l}\text { Розовая воз- } \\
\text { душная масса }\end{array}$ & $\begin{array}{l}\text { Розовая воз- } \\
\text { душная масса }\end{array}$ & $\begin{array}{l}\text { Розовая воз- } \\
\text { душная масса }\end{array}$ & $\begin{array}{c}\text { Бледно-розовая } \\
\text { воздушная масса }\end{array}$ \\
\hline Формоустойчивость & $\begin{array}{l}\text { Имеет рав- } \\
\text { номерную } \\
\text { форму, со- } \\
\text { храняет ри- } \\
\text { сунок на по- } \\
\text { верхности }\end{array}$ & $\begin{array}{c}\text { Расплывается, } \\
\text { не имеет чет- } \\
\text { кой формы, не } \\
\text { сохраняет ри- } \\
\text { сунок на по- } \\
\text { верхности }\end{array}$ & $\begin{array}{c}\text { Имеет равно- } \\
\text { мерную фор- } \\
\text { му, сохраняет } \\
\text { рисунок на } \\
\text { поверхности }\end{array}$ & $\begin{array}{c}\text { Имеет равно- } \\
\text { мерную фрор- } \\
\text { му, сохраняет } \\
\text { рисунок на } \\
\text { поверхности }\end{array}$ & $\begin{array}{c}\text { Расплывается, } \\
\text { не имеет четкой } \\
\text { формы, не со- } \\
\text { храняет рисунок } \\
\text { на поверхности }\end{array}$ \\
\hline Цвет & Белый & $\begin{array}{c}\text { Выраженный } \\
\text { розовый }\end{array}$ & $\begin{array}{l}\text { Выраженный } \\
\text { розовый }\end{array}$ & $\begin{array}{l}\text { Выраженный } \\
\text { розовый }\end{array}$ & Бледно-розовый \\
\hline Консистенция & $\begin{array}{l}\text { Воздушная } \\
\text { однородная }\end{array}$ & $\begin{array}{c}\text { Жидкая одно- } \\
\text { родная }\end{array}$ & $\begin{array}{l}\text { Воздушная } \\
\text { однородная }\end{array}$ & $\begin{array}{l}\text { Воздушная } \\
\text { однородная }\end{array}$ & $\begin{array}{c}\text { Жидкая, неодно- } \\
\text { родная с включе- } \\
\text { ниями коагули- } \\
\text { рованного белка }\end{array}$ \\
\hline Запах & $\begin{array}{c}\text { Легкий запах } \\
\text { печеных яб- } \\
\text { лок }\end{array}$ & $\begin{array}{c}\text { Выраженный } \\
\text { запах черной } \\
\text { смородины }\end{array}$ & $\begin{array}{c}\text { Выраженный } \\
\text { запах черной } \\
\text { смородины }\end{array}$ & $\begin{array}{c}\text { Выраженный } \\
\text { запах черной } \\
\text { смородины и } \\
\text { яичного аль- } \\
\text { бумина }\end{array}$ & $\begin{array}{c}\text { Выраженный } \\
\text { запах черной } \\
\text { смородины и } \\
\text { яичного альбу- } \\
\text { мина }\end{array}$ \\
\hline Вкус & Сладкий & $\begin{array}{c}\text { Насыщенный } \\
\text { кисло-сладкий } \\
\text { вкус }\end{array}$ & $\begin{array}{c}\text { Насыщенный } \\
\text { кисло-сладкий } \\
\text { вкус }\end{array}$ & $\begin{array}{c}\text { Насыщенный } \\
\text { кисло-сладкий } \\
\text { вкус с горчин- } \\
\text { кой }\end{array}$ & $\begin{array}{c}\text { Насыщенный } \\
\text { кисло-сладкий } \\
\text { вкус с горчинкой }\end{array}$ \\
\hline
\end{tabular}

Таблица 3

Физико-химические показатели и показатели безопасности зефира с добавлением комплекса антоциановый пигмент - яичный альбумин

\begin{tabular}{|c|c|c|c|}
\hline Показатель & $\begin{array}{l}\text { Нормативный } \\
\text { показатель }\end{array}$ & $\begin{array}{c}\text { Зефрир с добавлением } \\
\text { комплекса антоциановый } \\
\text { пигмент жимолости - } \\
\text { яичный альбумин } \\
\end{array}$ & $\begin{array}{l}\text { Зефир с добавлением ком- } \\
\text { плекса антоциановьй } \\
\text { пигмент черной смороди- } \\
\text { ны - яичный альбумин }\end{array}$ \\
\hline 1 & 2 & 3 & 4 \\
\hline \multicolumn{4}{|c|}{ Физико-химические показатели } \\
\hline Массовая доля влаги, \% & - & $20,7 \pm 0,4$ & $16,6 \pm 0,4$ \\
\hline $\begin{array}{l}\text { Массовая доля золы, нераство- } \\
\text { римой в растворе соляной ки- } \\
\text { слоты с массовой долей } 10 \%, \%\end{array}$ & - & $0,100 \pm 0,007$ & $0,081 \pm 0,007$ \\
\hline $\begin{array}{l}\text { Массовая доля общей сернистой } \\
\text { кислоты, \% }\end{array}$ & - & $0,009 \pm 0,001$ & $0,010 \pm 0,001$ \\
\hline \multicolumn{4}{|c|}{ Показатели безопасности } \\
\hline \multicolumn{4}{|l|}{ Токсичные элементы, мг/кг: } \\
\hline свинец & 1,0 & $<0,04$ & $<0,04$ \\
\hline Мышьяк & 1,0 & $0,022 \pm 0,009$ & $0,026 \pm 0,01$ \\
\hline
\end{tabular}


Окончание табл. 3

\begin{tabular}{|c|c|c|c|}
\hline 1 & 2 & 3 & 4 \\
\hline \multicolumn{4}{|c|}{ Микробиологические показатели } \\
\hline $\begin{array}{l}\text { Патогенные, в том числе саль- } \\
\text { монеллы, в } 25 \text { г }\end{array}$ & Не доп. & Отс. & Не обн. \\
\hline КМАФАнМ, КОЕ/г & $\begin{array}{l}\text { Не более } \\
1 \times 10^{3}\end{array}$ & $<100$ & $<100$ \\
\hline БГКП (колиформы), в 1,0 г & Не доп. & Отс. & Отс. \\
\hline Плесени, КОЕ/г & $\begin{array}{c}\text { Не более } \\
100\end{array}$ & $<10$ & $<10$ \\
\hline Дрожжи, КОЕ/г & Не более 50 & $<10$ & $<10$ \\
\hline
\end{tabular}

Результаты исследований показали, что все фризико-химические показатели и показатели безопасности зефира с добавлением комплекса антоциановый пигмент - яичный альбумин соответствуют нормативным значениям.

Выводы. Таким образом, введение в систему яичного альбумина и БСА влияет на интенсивность извлечения антоцианового пигмента из ягод жимолости и черной смородины. Введение в раствор 0,1\% яичного альбумина и БСА позволяет наиболее интенсивно выделять антоциановый пигмент из ягод смородины и жимолости. Увеличение белков в системе приводит к падению интенсивности извлечения антоцианового пигмента. Установлена зависимость степени извлечения антоцианового пигмента от pH раствора, содержащего пигмент и белок. Показано, что максимальной степени извлечения соответствует наименьшее значение $\mathrm{pH}$ системы. Рассмотрена возможность использования комплекса антоциановый пигмент - яичный альбумин в производстве зефира. Наилучшими органолептическими показателями обладал зефир с добавлением комплекса, содержащего $6 \%$ антоцианового пигмента и $2 \%$ яичного альбумина.

\section{Литература}

1. Britton G. (1986). Biokhimiya prirodnykh pigmentov [Biochemistry of natural pigments]. M., 422 c. [Cambridge University Press, Cambridge, 1983].

2. Mineo S., Noguchi A., Nagakura Y., Kobori K., Ohta T., Sakaguchi E. Ichiyanagi T. Boysenberry polyphenols suppressed elevation of plasma triglyceride levels in rats // J. of Nutritional Science and Vitaminology. - 2015. - 61(4). 306-312.
3. Sorrenti V., Vanella L., Acquaviva R., Cardile V., Giofre S., Di Giacomo Cyanidin induces apoptosis and differentiation in prostate cancer cells. International / J. of Oncology. - 2015. - 47(4). 1303-1210.

4. Mazewski C., Liang K., Gozalez de Mejia E. Inhibitory potential of anthocyanin-rich purple and red corn extracts on human colorectal cancer cell proliferation in vitro // J. of Functional Foods. - 2017. - 34. - 254-265.

5. Nems A., Peksa A., Kucharska A., SokolLetowska A., Kita A., Drozdz W., Hamouz K. (2015). Anthocyanin and antioxidant activity of snacks with colored potato // Food Chemistry. - 2012. - 172. - 175-182.

6. Flanigan P.M., Niemeyer E.D. Effect of cultivar on phenolic levels, anthocyanin composition, and antioxidant properties in purple basil (Ocimum basilicum L.) // Food Chemistry. 2014. - 164. - 518-526.

7. Jampani C., Rahavarao K. Process integration for purification and concentration of red cabbage (Brassica oleracea L.) anthocyanins // Separation and Purification Technology. 2015. - 141. - 10-16.

8. Liu S., Fu Y., Nian S. Buffering color fluctuation of purple sweet potato anthocyanins to acidity variation by surfactants // Food Chemistry. - 2014. - 162. - 16-21.

9. Valdes A., Vidal L., Beltran A., Canals S., Garrigos M.C. Microwave-assisted extraction of phenolic compounds from almond skin byproducts (prunus amygdalus) a multivariate analysis approach // J. Agric Food Chem. 2015. - 63. - 5395-5402.

10. Chesnokova N.Yu., Levochkina. L.V., Prikhod'ko Yu.V., Kuznetsova A.A., Vladykina $T . V$. Influence of polysaccharide functional groups on the extraction degree of blackcur- 
rant anthocyanin pigment // Pham Sci. \& Res. 2018. - 10(3). - 659-661.

11. Влияние желатина на степень выделения антоцианового пигмента жимолости и черной смородины / Н.Ю. Чеснокова, Л.В. Левочкина, Ю.В. Приходько [и др.] // Техника и технология пищевых производств. - 2017. № 4(47). - С. 92-97.

12. Сборник основных рецептур сахаристых кондитерских изделий / сост. Н.С. Павлова. - СПб.: ГИОРД, 2000. - 232 с.

\section{Literatura}

1. Britton G. (1986). Biokhimiya prirodnykh pigmentov [Biochemistry of natural pigments]. M., 422 s. [Cambridge University Press, Cambridge, 1983].

2. Mineo S., Noguchi A., Nagakura Y., Kobori K., Ohta T., Sakaguchi E. Ichiyanagi T. Boysenberry polyphenols suppressed elevation of plasma triglyceride levels in rats // J. of Nutritional Science and Vitaminology. - 2015. 61(4). - 306-312.

3. Sorrenti V., Vanella L., Acquaviva R., Cardile V., Giofre S., Di Giacomo Cyanidin induces apoptosis and differentiation in prostate cancer cells. International / J. of Oncology. - 2015. 47(4). - 1303-1210.

4. Mazewski C., Liang K., Gozalez de Mejia E. Inhibitory potential of anthocyanin-rich purple and red corn extracts on human colorectal cancer cell proliferation in vitro // J. of Functional Foods. - 2017. - 34. - 254-265.

5. Nems A., Peksa A., Kucharska A., SokolLetowska A., Kita A., Drozdz W., Hamouz K. (2015). Anthocyanin and antioxidant activity of snacks with colored potato // Food Chemistry. - 2012. - 172. - 175-182.

6. Flanigan P.M., Niemeyer E.D. Effect of cultivar on phenolic levels, anthocyanin composition, and antioxidant properties in purple basil (Ocimum basilicum L.) // Food Chemistry. 2014. - 164. - 518-526.

7. Jampani C., Rahavarao K. Process integration for purification and concentration of red cabbage (Brassica oleracea L.) anthocyanins // Separation and Purification Technology. 2015. - 141. - 10-16.

8. Liu S., Fu Y., Nian S. Buffering color fluctuation of purple sweet potato anthocyanins to acidity variation by surfactants // Food Chemistry. - 2014. - 162. - 16-21.

9. Valdes A., Vidal L., Beltran A., Canals S., Garrigos M.C. Microwave-assisted extraction of phenolic compounds from almond skin byproducts (prunus amygdalus) a multivariate analysis approach // J. Agric Food Chem. 2015. - 63. - 5395-5402.

10. Chesnokova N.Yu., Levochkina. L.V., Prikhod'ko Yu.V., Kuznetsova A.A., Vladykina T.V. Influence of polysaccharide functional groups on the extraction degree of blackcurrant anthocyanin pigment // Pharm Sci. \& Res. - 2018. 10(3). - 659-661.

11. Vliyanie zhelatina na stepen' vydeleniya antocianovogo pigmenta zhimolosti i chernoj smorodiny / N.Yu. CHesnokova, L.V. Levochkina, Yu.V. Prihod'ko [i dr.] // Tekhnika i tekhnologiya pishchevyh proizvodstv. 2017. - № 4(47). - S. 92-97.

12. Sbornik osnovnyh receptur saharistyh konditerskih izdelij / cost. N.S. Pavlova. SPb.: GIORD, 2000. - $232 \mathrm{~s}$. 